\title{
PHYTOCHEMICAL AND ANTIOXIDANT ACTIVITY OF CAMELLIA MISTLETOE (KORTHALSELLA JAPONICA) EXTRACTS
}

\author{
MIN YOUNG KIM* \\ Department of ???, Toxicology Laboratory, Faculty of Biotechnology (Biomaterials), College of Applied Life Science, SARI, Jeju National \\ University, Jeju, Republic of Korea. Email: jeffmkim@jejunu.ac.kr
}

Received: 31 August 2017, Revised and Accepted: 06 October 2017

\section{ABSTRACT}

Objective: This study was aimed to analyze the methanol or ethanol extract of Camellia mistletoe (Korthalsella japonica) growing in Jeju Island, Korea, for their composition of phenolics, flavonoids, and their antioxidant activity.

Methods: Total flavonoid, total carotenoid and L-ascorbic acid contents were determined by using colorimetric assays, and the antioxidant attributes of the methanol and Camellia mistletoe extracts were assayed using in vitro models, including the following: Free radical (1,1-diphenyl-2-picrylhydrazyl, $\mathrm{O}_{2}^{\cdot}$ and $\mathrm{NO}^{*}$ )scavenging, reducing power, and chelating ferrous ions.

Results: Total flavonoid, total carotenoid and L-ascorbic acid contents were 20.3 and $14.9 \mathrm{mg} \mathrm{RE} / 100 \mathrm{~g}$, 4.4 and $1.7 \mathrm{mg} / 100 \mathrm{~g}$, and 0.4 and $1.4 \mathrm{mg}$ $\mathrm{AA} / 100 \mathrm{~g}$ in the methanol and ethanol extracts of Camellia mistletoe, respectively. Based on $\mathrm{IC}_{50}$ values, both extracts were also found to possess potent antioxidant activities.

Conclusions: Camellia mistletoe extracts could be the good antioxidant source and holds promise as a natural ingredient in functional food and pharmaceutical supplement.

Keywords: Camellia mistletoe, Total flavonoid content, Total carotenoid content, Ascorbic acid content, Antioxidant activity.

(c) 2017 The Authors. Published by Innovare Academic Sciences Pvt Ltd. This is an open access article under the CC BY license (http://creativecommons. org/licenses/by/4. 0/) DOI: http://dx.doi.org/10.22159/ajpcr.2017.v10i12.22342

\section{INTRODUCTION}

Mistletoes (families Loranthaceae and Viscaceae) are small semiparasitic evergreen shrubs that grow on a variety of trees and are particularly noticeable on leafless winter trees. Mistletoes have recently been described to be both an agricultural pest and a threatened species in different parts of the world, because they live in an intimate association with their hosts, derive nutrition from the host and share a life-long association with a single individual host. Mistletoes are also of great economic importance due to their major use in the medical treatment and management of many diseases for many years. They are used as traditional and complementary medicine in treatment for cough, diabetes, hypertension, cancer, diuretic, smallpox, ulcer, skin infection, and after childbirth [1-3]. It has been suggested that pharmacologically active compounds may pass from a variety of host trees to the parasitic mistletoe plants [4].

Mistletoes are native to Asia, Africa, Europe, and Australia, and 70-100 species have been recorded [5]. There are three genera and six species of mistletoes in Korea [6]. Camellia mistletoe, Korthalsella japonica (family Santalaceae), is one of the species which is distributed in Jeju Island, Korea. Although previous research revealed that mistletoe has a higher antioxidant activity that has been using for treatment of many diseases, most investigative work has been done on the European mistletoe, Viscum album L. [7]. Therefore, the present study was aimed to analyze the bioactive contents of total flavonoids, total carotenoids and L-ascorbic acid, and investigate in vitro antioxidant activities of methanol and ethanol extracts of Camellia mistletoe ( $K$. japonica) through radical (1,1-diphenyl-2-picrylhydrazyl [DPPH], $\mathrm{O}_{2}^{-{ }^{*}}$ and $\left.\mathrm{NO}^{*}\right)$ scavenging, ferrous ion chelating and ferric reducing power. We also extended our previous work [8] by harvesting plants at a different time and optimizing sample preparation procedures.

\section{METHODS}

\section{Chemicals and reagents}

Rutin, aluminum chloride, metaphosphoric acid, L-ascorbic acid, sodium nitrite, DPPH, sodium nitroprusside, Griess reagent, ferric chloride, potassium ferricyanide, and trichloroacetic acid (TCA) were purchased from Sigma-Aldrich (MO, USA). All ingredients used in this study were of analytical grade.

\section{Plant material and extraction procedure}

Camellia mistletoe ( $K$. japonica) samples were collected during May 2015 from Camellia Hill located in Andeok-myeon, Seogwipo-si, Jeju-do Province, South Korea, and the voucher specimens (KHUP-0803) have been deposited in the herbarium of College of Applied Life Science, Jeju National University. Samples were prepared using a previously described protocol [9]. Briefly, the plant sample was rinsed, weighed and then ground into a fine powder using a blender. Portions (20 g) of the powdered sample were extracted with $100 \mathrm{~mL}$ of $100 \%$ methanol or $70 \%$ ethanol for $72 \mathrm{hrs}$ at room temperature with constant shaking. The mixture was then centrifuged at $1000 \times \mathrm{g}$ for 15 minutes and the supernatant then purified using a Sep-Pak $\mathrm{C}_{18}$ cartridge and a $0.45 \mu \mathrm{m}$ membrane filter (Waters, Milford, MA, US), concentrated using a rotary evaporator (Buchi Rotavapor R-200, New Castle, DE, US), freeze-dried and stored at $-20^{\circ} \mathrm{C}$ in storage vials for experimental use.

\section{Total flavonoid content (TFC)}

TFC of the extracts was determined by the aluminum chloride colorimetric method [10]. In brief, $15 \mu \mathrm{L}$ of each extract in methanol was mixed with $4.5 \mu \mathrm{L}$ of $5 \% \mathrm{NaNO}_{2}, 60 \mu \mathrm{L}$ of distilled water, and 4.5 $\mu \mathrm{L}$ of $10 \% \mathrm{AlCl}_{3}$. After incubation for $6 \mathrm{~min}, 60 \mu \mathrm{L}$ of $\mathrm{NaOH}$ solution (4\%) was added to the mixture and made up to a final volume of $150 \mu \mathrm{L}$ with distilled water. The mixture was allowed to stand for 15 minutes, and absorbance was measured at $510 \mathrm{~nm}$. TFC was calculated from a 
calibration curve, and the result was expressed as mg rutin equivalent (RE) per $100 \mathrm{~g}$ dry weight (mg RE/100 g).

\section{Total carotenoid content}

An aliquot of the extracts was used for quantification of total carotenoid content (TCC) using a Spectra MR microplate reader (Dynex Technologies, Inc., Chantilly, VA, US). TCC was calculated by measuring the absorbance at 470,653, and $666 \mathrm{~nm}$ according to the equations reported previously and expressed as $\mathrm{mg} / 100 \mathrm{~g}$ [11]. All operations were carried out on ice under dim light to prevent photodegradation, isomerizations and structural changes of the carotenoids.

\section{Ascorbic acid content}

Ascorbic acid content of the extracts was determined following the procedures as described earlier [12]with some modifications. The extract $(0.15 \mathrm{~g})$ was treated with $10 \mathrm{~mL}$ of $1 \%$ metaphosphoric acid (pH 1.86) in a rotary mixer at $200 \mathrm{rpm}$ for 45 minutes in the dark. After centrifuging at $1600 \times \mathrm{g}$ and $4^{\circ} \mathrm{C}$ for 15 minutes, the supernatant was collected. A portion of supernatant $(25 \mu \mathrm{L})$ was mixed with 225 $\mu \mathrm{L}$ of 2,6 -dichloroindophenol $(0.3 \mathrm{mg} / \mathrm{mL})$, and the absorbance was measured at $515 \mathrm{~nm}$ within 15 seconds. Content of ascorbic acid was calculated on the basis of the calibration curve of authentic L-ascorbic acid and was expressed as mg ascorbic acid per $100 \mathrm{~g}$ dry matter (mg $\mathrm{AA} / 100 \mathrm{~g})$.

\section{Scavenging of free radicals}

DPPH, superoxide anion and nitric oxide free radical scavenging activities of extracts were determined as described in our recently published paper [10]. A dose-response curve was plotted to determine the $\mathrm{IC}_{50}$ values which are defined as the concentration sufficient to obtain $50 \%$ of a maximum scavenging capacity. All tests were performed in triplicate.

\section{Ferrous ion chelating}

The ferrous ion chelating ability of extracts was determined as described earlier [10]. Briefly, $250 \mu \mathrm{L}$ of the extract was mixed with $5 \mu \mathrm{L}$ of $2 \mathrm{mM}$ ferrous chloride $\left(\mathrm{FeCl}_{2}\right)$. The reaction was initiated by the addition of $10 \mu \mathrm{L}$ of $5 \mathrm{mM}$ ferrozine and then incubated at $25^{\circ} \mathrm{C}$ for 10 minutes. The absorbance of the reaction mixtures was measured at $562 \mathrm{~nm}$ against blank samples.

\section{Ferric reducing power}

$\mathrm{The}^{3+} \mathrm{F}^{3+}$ reducing power of extracts was determined by the method of Huang et al. [13]. The extract $(200 \mu \mathrm{L})$ at various concentrations was mixed with $200 \mu \mathrm{L}$ of $0.2 \mathrm{M}$ phosphate buffer (pH 6.6) and an equal volume of potassium ferricyanide $\left[\mathrm{K}_{3} \mathrm{Fe}(\mathrm{CN})_{6}\right](1 \%, \mathrm{w} / \mathrm{v})$, followed by incubating at $50^{\circ} \mathrm{C}$ for 20 minutes. The reaction was stopped by adding $200 \mu \mathrm{L}$ of $10 \%$ TCA solution and then centrifuged at $800 \times \mathrm{g}$ for 10 minutes. $100 \mu \mathrm{L}$ of the supernatant was mixed with $100 \mu \mathrm{L}$ of distilled water and $20 \mu \mathrm{L}$ of $0.1 \%(\mathrm{w} / \mathrm{v}$ ) ferric chloride solution and the absorbance was measured at $700 \mathrm{~nm}$. Higher absorbance of the reaction mixture indicated greater reducing power

\section{Statistical analysis}

Data were analyzed using SPSS statistical software (SPSS, ver. 12.0; SPSS Inc., Chicago, IL, US). All measurements were carried out in replicate $(n=3)$. A dose-response curve was plotted to determine the $\mathrm{IC}_{50}$ values which are defined as the concentration sufficient to obtain $50 \%$ of a maximum scavenging capacity. Comparisons of all results between methanol and ethanol extracts of Camellia mistletoe were made using a non-parametric test (Mann-Whitney U test)with $\mathrm{p}<0.05$.

\section{RESULTS AND DISCUSSION}

\section{Phytochemical contents}

Phenolic compounds, aromatic secondary plant metabolites, which mainly include flavonoids, carotenoids, and L-ascorbic acid, and exhibit high antioxidant activity, and their consumption has been linked to a decreased risk of developing chronic and degenerative diseases [14]. In this study, the total flavonoid, total carotenoid and ascorbic acid contents, as well as antioxidant activities (radical scavenging, ferrous ion chelating and ferric reducing power) of methanol and ethanol extracts of Camellia mistletoe ( $K$. japonica) were quantified. TFC of the methanol and ethanol extracts, calculated from the calibration curve $\left(\mathrm{R}^{2}=0.999\right)$, were 20.3 and $14.9 \mathrm{RE} \mathrm{g} / 100 \mathrm{~g}$, respectively (Table 1$)$. The methanol extract contained higher total flavonoids than the ethanol extract $(p<0.05)$. Flavonoids, including flavones, flavanols, and condensed tannins, are plant secondary metabolites, the antioxidant activity of which depends on the presence of free $\mathrm{OH}$ groups, especially 3-OH. Plant flavonoids have antioxidant activity in vitro and also act as antioxidants in vivo [15]. Recently, Vicas et al. [16]reported that the TFC of the ethanol extracts of mistletoe $V$. album harvested from six different hosts were $0.05-2.19 \mathrm{mg} \mathrm{RE} / 100 \mathrm{~g}$, which is $6.8-324$ folds lower than that of the ethanol extract (14.9 mg RE/100 g) in our study (Table 1). This implies that differences of secondary metabolites in mistletoes are influenced by the kind of host plants and the type of solvents used for extraction.

Oxidative properties of plant extracts were tested by determining the contents of essential cellular antioxidants that are enzymes SOD, POX, and low molecular weight non-enzymatic antioxidants: Carotenoids and ascorbic acid and glutathione [17]. Carotenoids, vegetable dyes present in the chloroplasts and chromophores, play an auxiliary role in the process of photosynthesis [18]. In addition, ascorbic acid, as well as carotenoids also have a protective function against photo-oxidation processes. Carotenoids and ascorbic acid present in the tissues of studied plants may also act as scavengers of free radicals. Effectively inactivate singlet oxygen, and also react with organic free radicals produced during the process of lipid peroxidation [18]. In our study, total carotenoid and ascorbic acid contents in the camellia mistletoe extracts ranged from 1.7 to $4.4 \mathrm{mg} / 100 \mathrm{~g}$ and from 0.4 to $1.4 \mathrm{mg} \mathrm{AA} / 100 \mathrm{~g}$, respectively (Table 1). The methanol extract of camellia mistletoe had significantly higher TCC than the ethanol extract, whereas the lower amount of L-ascorbic acid was found in the ethanol extract of Camellia mistletoe $(\mathrm{p}<0.05)$ (Table 1$)$. This result may be due to the solubility of ascorbic acid and carotenoid compounds. The carotenoid and ascorbic acid contents of the European mistletoe ( $V$. album) have been reported to be $0.2-0.6 \mathrm{mg} / 100 \mathrm{~g}$ and $0.12-0.14 \mathrm{mg} \mathrm{AA} / 100 \mathrm{~g}$, respectively [19].

\section{Antioxidant activities}

Free radicals are involved in many disorders such as inflammation, heart disease, diabetes, gout, and cancer [20]. Antioxidants, due to their scavenging activity, are useful for the management of these diseases. As seen in Table 2, the methanol extract $\left(\mathrm{IC}_{50}=0.5 \mathrm{mg} / \mathrm{mL}\right)$ of Camellia mistletoe possess significantly higher DPPH scavenging activity than that of the ethanol extract $\left(\mathrm{IC}_{50}=0.7 \mathrm{mg} / \mathrm{mL}\right)(\mathrm{p}<0.05)$. However, the methanol extract showed similar scavenging activities for superoxide and nitric oxide radicals as ethanol extract (Table 2).

Iron is essential for life as it is required for oxygen transport, respiration and activities of many enzymes. Chelating agents inhibit lipid peroxidation by stabilizing the transition metals [21]. Decrease

Table 1: Total flavonoid, carotenoid and L-ascorbic acid contents of the methanol and ethanol extracts from Camellia mistletoe (K. japonica)

\begin{tabular}{llll}
\hline Solvent & Total flavonoid $(\mathbf{m g ~ R E} / \mathbf{1 0 0} \mathbf{g})$ & Total carotenoid $\mathbf{( m g / \mathbf { 1 0 0 }} \mathbf{g})$ & L-ascorbic acid $(\mathbf{m g}$ AA/100 g) \\
\hline $100 \% \mathrm{MeOH}$ & $20.3 \pm 0.76^{*}$ & $4.4 \pm 0.02 *$ & $0.4 \pm 0.09^{*}$ \\
$70 \% \mathrm{EtOH}$ & $14.9 \pm 0.16$ & $1.7 \pm 0.01$ & $1.4 \pm 0.13$ \\
\hline RE: Rutin equivalent, AA: L-ascorbic acid, *Values of $100 \% \mathrm{MeOH}$ are significantly different from corresponding $70 \% \mathrm{EtOH}(\mathrm{p}<0.05)$. K japonica: Korthalsella japonica
\end{tabular}


in the red color ferrozine- $\mathrm{Fe}^{2+}$ complex indicates higher scavenging activity of the compound. The metal chelating ability of the methanol and ethanol extracts of the Camellia mistletoe was represented in Fig. 1. The chelating effect of the extracts increases with the increase in concentration. Chelating effect on ferrous ions of the Camellia mistletoe extracts was $73-95 \%$ at $1.0 \mathrm{mg} / \mathrm{mL}$. The $\mathrm{IC}_{50}$ value for the chelating effect of the methanol extract was $0.5 \mathrm{mg} / \mathrm{mL}$, which was higher than that of the ethanol extract $(0.4 \mathrm{mg} / \mathrm{mL})(\mathrm{p}<0.05)$ (Fig. 1). EDTA used as positive control showed $99 \%$ at $0.5 \mathrm{mg} / \mathrm{mL}$. The results suggest that the

Table 2: $\mathrm{IC}_{50}$ value in free radical scavenging property of the methanol and ethanol extracts of Camellia mistletoe (K. japonica)

\begin{tabular}{llll}
\hline \multirow{2}{*}{ Solvent } & \multicolumn{3}{l}{ IC $_{50}$ value $(\mathrm{mg} / \mathrm{mL})$} \\
\cline { 2 - 4 } & DPPH & Superoxide anion & Nitric oxide \\
\hline $100 \% \mathrm{MeOH}$ & $0.5 \pm 0.001^{*}$ & $0.4 \pm 0.03$ & $0.7 \pm 0.01$ \\
$70 \% \mathrm{EtOH}$ & $0.7 \pm 0.003$ & $0.4 \pm 0.02$ & $0.7 \pm 0.02$ \\
\hline
\end{tabular}

$\mathrm{IC}_{50}$ was obtained by interpolation from linear regression analysis; each value is expressed as mean \pm standard deviation $(n=3)$. *Value is significantly different from corresponding 70\% EtOH ( $\mathrm{p}<0.05)$. K. japonica: Korthalsella japonica

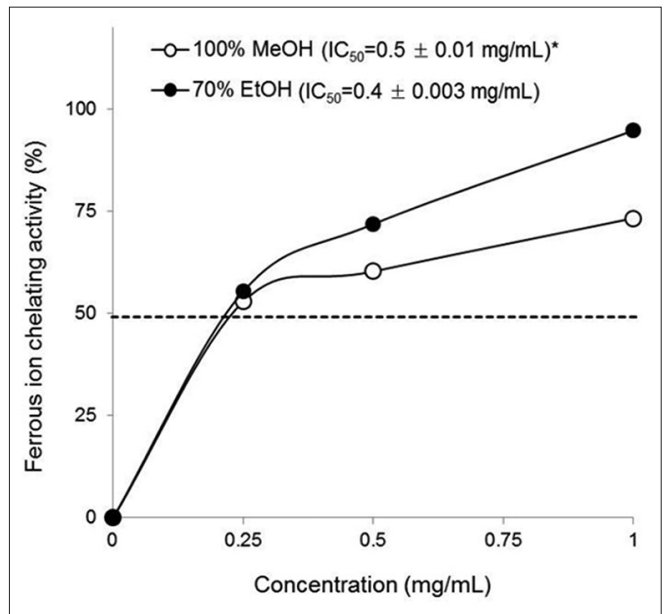

Fig. 1: Ferrous ion chelating ability of the methanol and ethanol extracts of obtained from Camellia mistletoe (Korthalsella japonica), each value is expressed as mean \pm standard deviation $(n=3)$ and $p<0.05$, compared to $70 \% \mathrm{EtOH}$

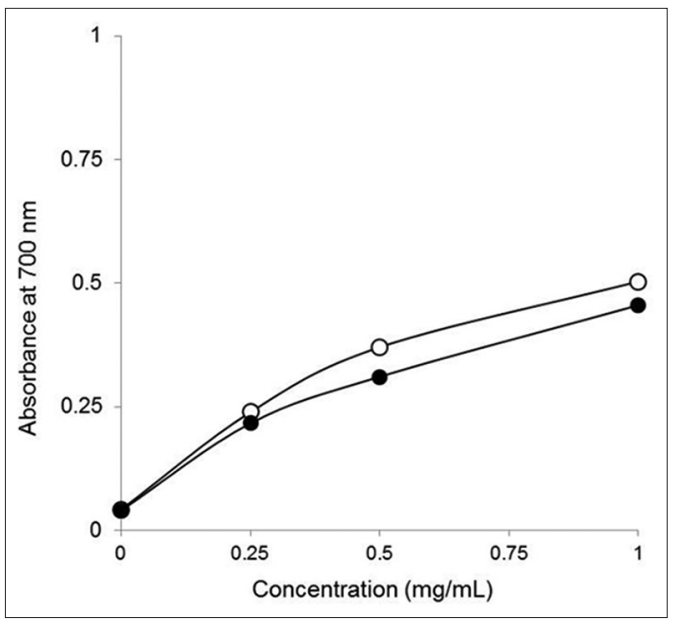

Fig. 2: Reducing power ability of the methanol and ethanol extracts obtained from Camellia mistletoe (Korthalsella japonica), each value is expressed as mean \pm standard deviation $(n=3)$
Camellia mistletoe extracts are capable of scavenging free radicals and prevent the initiation of free radicals by stabilizing them to participate in any deleterious reactions.

The conversion of $\mathrm{Fe}^{3+}$ to $\mathrm{Fe}^{2+}$ in the presence of extract and fractions was measured to determine the reducing power. The reducing properties are generally associated with the presence of reductones (antioxidants), which have been shown to exert antioxidant action by breaking the free radical chain [22]. The antioxidant constituents of the extract or fractions caused reduction of ferric-cyanide complex to the ferrous form due to hydrogen donation from phenolic compounds [22]. In this study, reducing the power of the Camellia mistletoe extracts was determined using ascorbic acid as the positive control. The reducing ability increased with concentration (Fig. 2). The maximum absorbance for crude extract was $0.43-0.47$ at $1.0 \mathrm{mg} / \mathrm{mL}$ compared to 0.64 of ascorbic acid at $0.25 \mathrm{mg} / \mathrm{mL}$ used as positive control.

\section{CONCLUSION}

Camellia mistletoe extracts have potent antioxidant properties and can be considered as a good source for the food industry and medicinal applications. Further, the phytochemical analysis is needed to isolate the compounds responsible for the wide spectrum of pharmacological activities.

\section{ACKNOWLEDGMENT}

This work was supported by Basic Science Research Program (2016R1A6A1A03012862 and 2014R1A1A2056292) through the National Research Foundation of Korea (NRF) funded by the Ministry of Education, Science and Technology, and by Business for Cooperative R\&D between Industry, Academy, and Research Institute (Grants No. C0345499) funded Korea Small and Medium Business Administration in 2015, Republic of Korea.

\section{REFERENCES}

1. Ishizu T, Winarno H, Tsujno E, Morita T, Shibuya H. Indonesian Medicinal Plants. XXIV. Stereochemical structure of perseitol-K ${ }^{+}$ complex isolated from the leaves of Scurrula fusca (Loranthaceae). Chem Pharm Bull 2002;50:489-92.

2. Kim MK, Yun KJ, Lim DH, Kim JJ, Jang YP. Anti-inflammatory properties of flavone di- $C$-glycosides as active principles of camellia mistletoe, Korthalsella japonica. Biomol Ther 2016;19:1-8.

3. Osadebe PO, Okide GB, Akabogu IC. Study on anti-diabetic activities of crude methanolic extracts of Loranthus micranthus (Linn.)sourced from five different host trees. J Ethnopharmacol 2004;95(2-3):133-8.

4. Büssing A, Schietzel M. Apoptosis-inducing properties of Viscum album L. extracts from different host trees, correlate with their content of toxic mistletoe lectins. Anticancer Res 1999;19:23-8

5. Zuber D. Biological flora of central Europe: Viscum album L. Flora 2004;199:181-203.

6. Lee CB. Korea flora. Seoul: Hyangmunsa; 1985, p. 295-6.

7. Hajtó T, Hostanska K, Berki T, Pálinkás L, Boldizsár F, Németh P. Oncopharmacological perspectives of a plant lectin (Viscum album Agglutinin-I): Overview of Recent Results from In vitro Experiments and In vivo Animal Models, and Their Possible Relevance for Clinical Applications. Evid Based Complement Alternat Med 2005;2(1):59-67.

8. Kang DH, Park EM, Kim JH, Yang JW, Kim JH, Kim MY. Bioactive compounds and antioxidant activity of Jeju camellia mistletoe (Korthalsella japonica Engl.). J Life Sci 2016;26:1074-81.

9. Kang DH, Kim MY. Antimicrobial activity of Korean camellia mistletoe (Korthalsella japonica (Thunb.)Engl.)extracts. J Appl Pharm Sci 2016;6:226-30.

10. Aharmas S, Saxena J. Phytochemical screening and quantitative estimation of total phenolic content and totoal flavonoid content of grains of Paspalum scrobiculatum. Asian J Pharm Clin Res 2016;9:73-6.

11. Rainha N, Lima E, Baptista J, Rodrigues C. Antioxidant properties, total phenolic, total carotenoid and chlorophyll content of anatomical parts of Hypericum foliosum. J Med Plants Res 2011;5:1930-40.

12. Klein BP, Perry AK. Ascorbic acid and vitamin A activity in selected vegetables from different geographical areas of the United States. J Food Sci 1982;47:941-5

13. Huang YC, Chang YH, Shao YY. Effects of genotype and treatment 
on the antioxidant activity of sweet potato in Taiwan. Food Chem 2006;98:529-38

14. Robbins RJ. Phenolic acids in foods: An overview of analytical methodology. J Agric Food Chem 2003;51(10):2866-87.

15. Atina RC, Irda F, Komar R. Comparison of five antioxidant assays for estimating antioxidant capacity from three Solanum SP. extracts. Asian J Pharm Clin Res 2016;9:123-8.

16. Vicas SI, Rugina D, Leopold L, Pintea A, Socaciu C. HPLC fingerprint of bioactive compounds and antioxidant activities of Viscum album from different host trees. Not Bot Horti Agrobot Cluj Napoca 2011;39:48-57.

17. Genet S, Kale RK, Baguer NZ. Alteration on antioxidant enzymes and oxidative damage in experimental diabetic rat tissue: Effect of vanadate and fenugreek (Trigonella faenum graeoum). Mol Cell Biochem 2002;236:7-12.
18. Sikora E, Cieślik E, Topolska K. The sources of natural antioxidants. Acta Sci Pol Technol Aliment 2008;7:5-17.

19. Barbasz A, Kreczmer B, Rudolphi-skórska E, Sieprawska A, Wožnica D. Content of antioxidants in extracts of mistletoe (Viscum album L.), yew (Taxus baccata L.), pine (Pinus sylvestris L.)and fir (Abies alba Mill.). Herba Pol 2012;58:27-36.

20. Slater TF. Free-radical mechanisms in tissue injury. Biochem J 1984;222(1):1-15

21. Serargui F, Baghiani A, Khennouf S, Arrar L. Antioxidant activity assessment of Tamus communis L. Roots. Int J Pharm Pharm Sci 2016;8:64-71

22. Vichit W, Nisakorn S. Antioxidant activities and cytotoxicity of Thai pigmented rice. Int J Pharm Pharm Sci 2015;7:329-34. 